\title{
Ethical capacity and its challenges in the academy of science: historical continuities and contemporary violence
}

\author{
Kjersti Lohne ${ }^{1}$ (D)
}

Received: 20 February 2020 / Accepted: 10 June 2020 / Published online: 20 June 2020

(c) The Author(s) 2020

\begin{abstract}
This reflective essay is inspired by a roundtable discussion at the World Science Forum on the question 'Are there ethical limits to what science can achieve and should pursue?' I argue that, amid the conflicting trends of 'technological utopianism' - extreme faith in technological solutions; and 'post-truth' politics—-the populist pushback against the universality of science, the conditions for ethical knowledge production are significantly challenged. Drawing on insights gleaned from my work on political violence, law, and technology, I point to historical continuities in the way the application and pursuit of science relates to violence-especially state violence. Conscious of the fact that science exercises no restraint on violence — and indeed, may be put to work for violent purposes - the paper calls for more attention to the social, structural, and political conditions of scientific production. The final part of this essay, therefore, examines three developments challenging the ethical capacity of scholars and scientists today. These are (1) the bureaucratization of ethics (2), 'ethics washing,' and (3) co-optation. Like other policy domains in our society, informed normative assessments around scientific pursuits-value judgments and ethical evaluation—ought to be based on sound empirical knowledge of the contingencies of science.
\end{abstract}

Keywords Ethics $\cdot$ Technological utopianism $\cdot$ Political violence $\cdot$ Science

\section{Introduction}

This reflective essay is inspired by a roundtable discussion at the World Science Forum on the question 'Are there ethical limits to what science can achieve and should pursue?' I was selected to participate in discussing this most critical and delicate of topics by the Global Young Academy. Taking the privilege of academics and the (relatively) young, my aim in this essay is to offer a critique, with a view to furthering critical consideration of the role of ethics in the pursuit of scientific and technological progress. I will argue that amid the conflicting trends of 'technological utopianism'extreme faith in technological solutions [1]; and 'post-truth' politics - the populist pushback against the universality of science, ${ }^{1}$ the conditions for ethical knowledge production are significantly challenged. Drawing on insights gleaned from my work on political violence, law, and technology, ${ }^{2}$ I point to historical continuities in the way the application

Kjersti Lohne

kjersti.lohne@jus.uio.no

1 Department of Public and International Law, Faculty of Law, University of Oslo, Oslo, Norway and pursuit of science relates to violence-especially state violence. Conscious of the fact that science exercises no restraint on violence-and indeed, may be put to work for violent purposes - the paper calls for more attention to the social, structural, and political conditions of scientific production. Science-like other industries-is subject to the political realities of professionalism, finance, and politics, as well as to the subtle power dynamics that characterize us as social beings. The final part of this essay, therefore, examines three developments that I regard as especially challenging to the ethical capacity of scholars and scientists today. These are (1) the bureaucratization of ethics (2), 'ethics

\footnotetext{
${ }^{1}$ Much has already been written on the concept and empirical claims of 'post-truth' politics since Oxford University Press declared 'posttruth' to be the Word of the Year 2016, but see, for example, Davies, William. "The age of post-truth politics." The New York Times 24 (2016): 2016; special issue on 'post-truth' in New Perspectives. Interdisciplinary Journal of Central \& East European Politics and International Relations 3(26), 2018; MacMullen, Ian. "Survey Article: What Is "Post-factual" Politics?." Journal of Political Philosophy (2019).

${ }^{2}$ Lohne, K (2019) Advocates of Humanity: Human Rights NGOs in International Criminal Justice. Oxford University Press. Oxford. Lohne, K (2012) 'The Norwegian Data Inspectorate: Between Governance and Resistance' Surveillance \& Society 10(2).
} 
washing,' and (3) co-optation-all of which deserve more scrutiny than they are given here, in order to assess their implication for basic science. Like other policy domains in our society, informed normative assessments around scientific pursuits-value judgments and ethical evaluation-ought to be based on sound empirical knowledge of the contingencies of science.

I will not address the roundtable question directly, but instead concern myself with the structures and agency that are embedded in this kind of questioning - the conditions of ethical judgment and ethical judges alike. The association made with law and legal judgment is not accidental. The spheres of law and ethics are both concerned with value judgments, and both set out to regulate behavior on the basis of such normative reasoning. However, law and ethics are not the same, and the relationship between them is very complex. ${ }^{3}$ As this paper will show, there is both too little and too much law determining the ethical limitations to science.

\section{Contradictions as points of departure}

The invocation of a general worldwide zeitgeist should always be accompanied by major caveats. ${ }^{4}$ Nonetheless, there seem to me to be three overarching contradictory trends that inform our condition today, and that are important for our consideration of the relationship between ethics and science. First, as was captured by the German sociologist Ulrich Beck in his writings on 'world risk society' [2, $3]$, and on entire schools of thought, ${ }^{5}$ we live in a situation where there is the perpetual threat of catastrophe. Indeed, scholars have likened the modern age to a permanent condition of crisis, where one crisis follows another, and where there is always an anticipation of catastrophe: from the atomic bomb, chemical, biological, and robotic warfare, to genome editing and artificial intelligence- the foundations of civilization as we know it are in the balance. There may be a breakdown ahead-a future unknown to us. At the same time, a second strand in contemporary thinking is a profound

\footnotetext{
3 The relationship between morals and law defines the discipline of legal philosophy.

${ }^{4}$ There is much reason to contest universal claims and 'grand theory' postulates, not the least because of the 'situatedness' of knowledge production in global hierarchies of power. See, for example, Connell, R. (2007). Southern Theory: The Global Dynamics of Knowledge in Social Science. Cambridge, Polity Press. Thus, my positionality in these global hierarchies and relations of power is one of speaking from the global north, which must be kept in mind when, for instance, the 'risk society' is taken as a worldly zeitgeist, rather than one anchored in a particular view of the world.

5 The field of Critical Security Studies especially has contributed insights into the meanings of 'security' for contemporary politics and social life.
}

faith in technological solutions to almost everything-an unprecedented progress narrative about the potential of science and technology to solve complex global challenges, which amounts to a form of 'technological utopianism' [1]. This faith in technological salvation conflicts with yet a third mindset, namely the populist pushback against the universality of science. The very idea of 'truth' seems up for grabsespecially in some circles-and expertise, including that of scientists, does no longer equate to power: expert authority is challenged by 'post-truth', or 'post-factual' politics. ${ }^{6}$ All this occurs in a context where the international order features increasing political turmoil and instability, and where, on a global scale, scientific, and technological advances carry the potential both to facilitate democratic participation and to undermine it altogether. A potent reminder of the latter possibility is the 2018 Facebook-Cambridge Analytica data scandal. The combination of data mining, data analysis, and strategic communication during electoral processes and referendums arguably influenced the outcomes of the 2017 presidential election in Kenya, the 2016 referendum on Brexit in the United Kingdom, and the 2016 presidential election in the USA which brought Donald Trump to power. ${ }^{7}$

These three elements-the anticipation of catastrophe, blind faith in technology and conflicting claims about empirical matter-are indicative of the volatility and velocity of our time-uncertain, accelerated, and impatient. Overtaken by the need to innovate and upgrade, moral philosophy has come to seem outdated; we now move in a time unfit for slow contemplation. By contrast, the realm of ethics seems to belong to a different temporality. As indicated by the roundtable question, ethics are viewed as limiting progress - an anachronism constraining future possibilities. Yet paradoxically, the need to stop— to pause for thought—has never been more urgent.

In the remainder of this article, I will examine the capacity of scholars and scientists to make ethical assessments of scientific pursuits. I will draw on insights from my research on political violence and international justice, and on the use of technology to prevent, mitigate, treat, and punish global violence. ${ }^{8}$ As a reminder of what is at stake, the next section addresses how scholars and scientific knowledge have been, and still are, put to work for violent (state) purposes, and how technological utopianism has conflated technical ability with normative assessments. Mindful of the situatedness

\footnotetext{
${ }^{6}$ MacMullen, I (2019), 'Survey Article: What is 'Post-factual' Politics?' Journal of Political Philosophy 28(1).

7 Lohne, K (2018), 'As the universal breaks: moments of awkwardness in international justice', New Perspectives-Interdisciplinary Journal of Central and East European Politics \& International Relations 3(26).

${ }^{8}$ Sandvik, K.B. \& K. Lohne, 'The Struggle against Sexual violence in Conflict: Investigating the Technological Turn', under review.
} 
of scholars and scientists, the section views science as a social field replete with structural restraints and opportunities that are in themselves in need of ethical consideration. I examine three trends I have identified as further challenges to the ethical capacity of scholars and scientists, namely the bureaucratization of research ethics, 'ethics washing,' and co-optation. In conclusion, I reiterate the need for scientific diplomacy and suggest that more attention should be given to the value of reclaiming ethical capabilities as part of the scientific ethos.

\section{Historical continuities and contemporary violence}

The Enlightenment brought with it a profound faith not only in scientific reason, but also in the sanctity of the individual human being - a belief that we have some innate and inalienable rights simply because we exist. The philosopher and mathematician, the Marquis de Condorcet, propagated a narrative of inevitable human progress, in which expanding knowledge in the natural sciences inevitably led to progress in morals and the political sciences. To some extent, this seemed to be justified.

For example, the Enlightenment inspired the modern human rights movement, with its rules for warfare, for governance, for how kings and other sovereigns can legitimately treat their citizens, and with its provisions for holding leaders criminally accountable if they violate these norms [4]. Despite the fact that human rights often exist more in theory than in practice, and that there is now considerable normative backlash [5], the last century did witness a decrease in human suffering, violence, and war-if we accept as the parameters of measurement: relative poverty and deaths caused by violent conflict. ${ }^{9}$ To some extent, perhaps, scientific and moral progress do correlate.

That said, though, science exercises no restraint on violence. In fact, throughout modern history, we know the contrary to have been the case-science has been applied by violent means and pursued for violent ends. We need only think of the Second World War, and remind ourselves that Germany was considered to be at the forefront of scientifically and technologically advanced human civilization, and that this position in no way led to any limitation of inhumanity [6]. In fact, scholars of mass violence point out how modern technology facilitated and exacerbated the scope and scale of the Holocaust - the number of killings would

\footnotetext{
${ }^{9}$ For popular science accounts of this development, see e.g., Pinker, Steven. The better angels of our nature: Why violence has declined. Penguin Group USA, 2012; Harari, Y. N. (2016). Homo Deus: A brief history of tomorrow. Random House.
}

simply not have been possible without the development of the industrial and technocratic state [7, 8].

I am not making a direct parallel with the role of scholars and scientists in the Third Reich, but in my research on contemporary political violence, scholars and scientists certainly do play a role. Science becomes part of power struggles-especially state power struggles. While there are many examples, I want to concentrate on the US-led Global War on Terror, as this exemplifies scientific applications and technological advances being put to use 'in good faith'-legitimated by liberal and humanitarian ideologies responding to global violence and disorder.

One example is the US Central Intelligence Agency's (CIA) counter-terrorism program after the September 11 terror attacks, where psychologists and lawyers alike facilitated and legitimated the use of torture. Contract psychologists allegedly designed, implemented, and oversaw the agency's torture program. ${ }^{10}$ While civil lawsuits brought against them by the ACLU ended in a settlement, psychologists are currently being called as witnesses in the pre-trial hearings of the September 11 case at Guantanamo Bay, where their leading role in designing and implementing the torture program is coming to light. Moreover, lawyers and legal scholars in the US administration adopted wide-ranging experimental legal interpretations that, in their view, legalized the use of interrogation techniques, otherwise known as torture. ${ }^{11}$ This was far from a unique case: national scientific and legal expertise was applied to legitimating and legalizing actions considered not only seriously unethical, but also manifestly unlawful by international standards, including the Convention against Torture and other Cruel, Inhuman or Degrading Treatment or Punishment.

In hindsight, or from a distance, these ethical and legal limits were clearly crossed. But up close, in everyday life, boundaries are often much more blurred. It may also be difficult to distinguish between what 'is' and what 'ought to be' - as with the roundtable question, what science can achieve and what science should achieve are two fundamentally different questions. It is imperative to be aware of this.

Another such case is the development toward autonomous warfare — using drones especially_and how the lack of distinction between, or conflation of argument between technical ability and moral judgement has become part of the problem. There is, for example, a belief that more precise weapons technology is 'humanizing' warfare. By

\footnotetext{
10 https://www.nytimes.com/interactive/2017/06/20/us/cia-tortu re.html,https://www.nytimes.com/2020/01/27/us/politics/cia-black -site-doctors.html.

11 https://www.intelligence.senate.gov/sites/default/files/publicatio ns/CRPT-113srpt288.pdf See also Johns, Fleur. (2013) Non-legality in international law: unruly law. Cambridge University Press. Cambridge.
} 
their supporters, drones are often presented as a humanitarian alternative to troop deployment, and 'a step forward in humanitarian technology'. ${ }^{12}$ Armed drones can be used to selectively eliminate targets that are killed with surgical precision; paradoxically this paves the way for drone strikes and extra-judicial killings to masquerade as something other than 'actual warfare'. Using them potentially lowers the threshold for the use of force. This means that the perceived technical ability to kill designated individuals may become the very rationale for doing so [1]. Rather than humanizing warfare, war becomes borderless, ubiquitous, and perpetual [9].

\section{Science as a social field}

The relationship between science, scientists, and muscular state power is one of the main reasons why science diplomacy and the World Science Forum are of such great importance. However, in discussions on research integrity and the independence of science, attention often focuses on whether science and technology are, in themselves, 'neutral,' and whether it is only applications of science and technology that can be employed for violent, harmful or otherwise unethical purposes. This is a discussion that presumes there is a clear-cut distinction between pure and applied science. However, this distinction is one of emphasis, not mutual exclusion. In addition to muscular state power, the science industry - like other industries - is also subject to and enmeshed in the political realities of professionalism, finance and politics. ${ }^{13}$ Scholars and scientists neither operate nor think inside a vacuum-they are not above and beyond power politics, or the subtle power dynamics that characterize us as social and political animals.

Ethics in science thus also concerns how we treat one another. Although there is great variation from state to state and from discipline to discipline, it is naïve to think that scientists' working conditions - that are characterized by shortterm fixed contracts, acute publication pressures, informal and formal hierarchies, and vulnerability to sexual harassment and mental health issues and burnout-do not circumscribe on the pursuit of science. In Norway, where I live and work, recent studies have shown how young scholars and scientists are especially prone to employing 'questionable research practices,' in the face of industry pressures to 'publish or perish' — rather than the individual's lack of moral integrity being to blame. ${ }^{14}$ Ethical limits to what science

\footnotetext{
12 Kenneth Anderson, 'Targeted Killing in US Counter-terrorism Strategy and Law', available at SSRN 1415070 (2009), 13.

13 There is an entire discipline devoted to the social study of science and technology.

14 See Norwegian media sources: https://forskning.no/forsknings etikk-medisin-og-helse-ntb/unge-forskere-opplever-uetisk-press
}

can achieve is also an issue that demands a good deal of introspection within our own research communities. How do we structure them to enable talented young scholars and scientist to thrive and progress? And, crucially, how do we make sure that future generations of scholars and scientists are up to the task of conducting research ethically, and to reflect on the ethical ramifications of their pursuits?

To make it possible to create and maintain structures and cultures for ethical reflection within the academy of science, there is a need to reflect more deeply and collectively on the ethical capacity of scholars and scientists when confronting the following three emerging trends namely, bureaucratization, ethics washing, and co-optation.

\section{Bureaucratization of Research Ethics}

There is a trend-in the EU at least-toward increasing bureaucratization and judicialization of research ethics. This reflects a growing tendency for law to take over ethics, and thereby the actual assessment of what is and what is not ethical scientific practice. Examples abound of ethical guidelines being treated $a s$ if they have legal content, and are therefore potential violations of contract. The question 'is this ethical?' is replaced with the question 'have you followed the rules?' Out the window goes actual ethical consideration, discussion, and reflection - the discursive space where scholars and scientists reflect on what is right and what is wrong, and, not the least, what the limits of scientific pursuit should be. Part of this debate is currently ongoing in the disciplines of anthropology and criminology, as the newly implemented GDPR within EU member states and its requirement of individual direct consent to data collection and management may stamp out the entire ethnographic method as well as qualitative research on marginalized and deviant populations $[10,11]$.

As part of this development, ethics are increasingly put into the hands of the ever-growing numbers of university administrators, research managers, and lawyers hired to respond to the bureaucratization of research ethics. This necessarily leads to the appropriation-or removal-of ethical capacity from the academy of science, that is, of the power to decide whether a science project is ethical or not. Besides stripping the academic community of ethical capacity, this development may also become a tool used by (state) administrators and private and public funders alike to censor de facto 'unfavorable' research findings. 'In a context of chronic underfunding of universities and their growing dependence on donor-driven research grants... [there is] a broader trend of donors and implementing partners who

Footnote 14 (continued)

/1625958?fbclid = IwAR0Q1RpA6uVNxLHhtV18G5avnsHtb4D4R sMBeG-V8wjdFgsOdAKny_DBoo0. 
deliberately use ethical and methodological arguments to undermine essential research' [12].

\section{Ethics washing}

On the other side of the coin is a development known colloquially as 'ethics washing': ethical frameworks are set upusually by private industry actors-to sidestep, or avoid, enforceable state regulation. Especially in technological development and innovation, "ethics is seen as the "easy" or "soft" option which can help structure and give meaning to existing self-regulatory initiatives. In this world, "ethics" is the new "industry self-regulation", [13].

At the same time, this also shows how private actorsespecially from industry-are increasingly involved in research governance, including its ethical dimensions. This matters, because it implies that science is not only subject to but also fundamentally driven by a market logic and temporality where ethics are viewed purely as limits to the pursuit of profits, rather than as value judgments on what is just and what is not, and for whom. 'When seen through this lens, ethical conduct cannot be seen as virtue or duty, it simply exists in order to prevent governmental regulation [13].' Questions must be asked not only about the relationship between powerful industry actors and the state, but also about how these power structures are exacerbated in the global south, where the potential for state regulation of transnational companies is even weaker. ${ }^{15}$ In this context, and contrary to the trend toward bureaucratizaton, there is too little law.

\section{Co-optation}

Finally, though this is by no means a new developmentquite the contrary - the relationship between science and those who finance it, and the risk that the former will be coopted by the latter, is one that demands constant attention. Because while the connection between power and knowledge have been recognized and exploited since the dawn of time, given the volatility and vulnerability of our planet and civilization alike, 'the connection [has] become acutely problematic and its comprehension of greatest urgency' [6]. The third and final element influencing the ethical capacity of scholars and scientists is thus the danger of their independence being co-opted by external stakeholders, who may exploit scientific and technological advances for unethical and even violent purposes. The fact that the bulk of state

\footnotetext{
15 Sandvik, Kristin, “'Is Legal Technology a New 'Moment' in the Law and Development Trajectory?" Antipode Online, December 4, 2019, available at: https://antipodeonline.org/2019/12/04/legal-techn ology-law-and-development/.
}

funding for scientific research is often directed toward military ends underlines this problem. But another, more subtle dynamic, is the increased focus on 'user involvement' and 'stakeholder engagement' in external research grants. For young researchers, the ability to obtain grants is tantamount to guaranteeing their excellence; some grants are so prestigious that they become golden tickets to tenure. These developments not only raise the question of how 'pure' basic science is, but also whether we academics actually call the shots-especially, perhaps, when it comes to determination of ethical limits to our pursuits. ${ }^{16}$

\section{Conclusion}

To conclude, I want to reiterate what a privilege it is to be a critical voice - a voice concerned with the greatest challenge that faces science and those fortunate enough to be its practitioners: namely to recognize the wisdom of restraint and slow ethical reflection. It seems to me that ethics and science move at different speeds, operating in different temporalities. Because in our quest for citations, funding, impact, innovation-for scientific break-throughs - there must be time to stand still — if only for a while — so that we (re)gain our capacity to consider not only whether our scientific pursuit is possible or not, but if it is something we want and value for our societies going forward.

Paradoxically, there is an urgency to the need to pause for thought now. Our times are challenged-threatened evenby an exponential growth of technologies as the international political order is destabilizing. The democratic backsliding that we see both within and beyond the EU is both constitutive by and of further political and social disruption. Independent scientific research is a pillar of knowledge-based democracy - of our collective decisions for a collective future, founded upon empirical and transparent knowledge of our contemporary situation. For these reasons, the relationship of ethics - limits and possibilities alike - to science is one that demands the continued attention and full capacity of the academy of science.

Acknowledgements Open Access funding provided by University of Oslo (incl Oslo University Hospital.

Funding No funding is received for this study.

\footnotetext{
${ }^{16}$ For those interested in dynamics between science, higher education, the state and market, see also the literature on 'academic capitalism', Slaughter, S., \& Leslie, L. L. (1997). Academic capitalism: Politics, policies, and the entrepreneurial university.
} 


\section{Compliance with ethical standards}

Conflict of interest The author(s) declare that they have no conflict of interest.

Open Access This article is licensed under a Creative Commons Attribution 4.0 International License, which permits use, sharing, adaptation, distribution and reproduction in any medium or format, as long as you give appropriate credit to the original author(s) and the source, provide a link to the Creative Commons licence, and indicate if changes were made. The images or other third party material in this article are included in the article's Creative Commons licence, unless indicated otherwise in a credit line to the material. If material is not included in the article's Creative Commons licence and your intended use is not permitted by statutory regulation or exceeds the permitted use, you will need to obtain permission directly from the copyright holder. To view a copy of this licence, visit http://creativecommons.org/licenses/by/4.0/.

\section{References}

1. Sandvik KB, Lohne K (2014) The rise of the humanitarian drone: giving content to an emerging concept". Millennium 43(1): 145-164

2. Beck U (1992) Risk society: towards a new modernity. Sage, London
3. Beck U (1999) World risk society. Polity Press, Cambridge

4. Sikkink K (2011) The justice cascade: how human rights prosecutions are changing world politics (the Norton series in world politics). WW Norton \& Company, New York

5. Hopgood S (2013) The endtimes of human rights. Cornell University Press, Ithaca

6. Cassidy DC (1992) Heisenberg, German science, and the third Reich. Soc Res 59(3):643-661

7. Bauman Z (2000) Modernity and the holocaust. Cornell University Press, Ithaca

8. Bauer Y (2002) Rethinking the holocaust. Yale University Press, New Haven

9. Gregory D (2011) 'The everywhere war. Geogr J 177(3):238-250

10. Dilger H, Pels P, Sleeboom-Faulkner M (2019) Guidelines for data management and scientific integrity in ethnography. Ethnography 20(1):3-7. https://doi.org/10.1177/1466138118819018

11. de Koning M, Meyer B, Moors A, Pels P (2019) Guidelines for anthropological research: data management, ethics, and integrity. Ethnography 20(2):170-174. https://doi.org/10.1177/1466138119 843312

12. Storeng KT, Palmer J (2019) When ethics and politics collide in donor-funded global health research. The Lancet 394(10193):184-186

13. Wagner B (2018) Ethics as an escape from regulation: from ethicswashing to ethics-shopping. Being profiling. Cogitas ergo sum 84-90:84 